\title{
Electrochemical study on the corrosion resistance of surface modified Cr-Mo-V steel by elevated temperature plasma nitriding
}

\author{
K Trinadh ${ }^{1}$, Corinne Nouveau ${ }^{2}$, A S Khanna ${ }^{3}$, Karanveer S Aneja ${ }^{3}$ and K Ram Mohan Rao ${ }^{4}$ () \\ 1 Department of Chemistry, GIS, Gandhi Institute of Technology \& Management, Rushikonda, Visakhapatnam -530045, Andhra Pradesh, \\ India \\ 2 Laboratories Bourguignon des Matériaux et Procédés (LaboMaP), Arts et Métiers ParisTech de Cluny, Rue Porte de Paris, F-71250, \\ Cluny, France \\ 3 Department of Metallurgical Engineering and Materials Science, Indian Institute of Technology Bombay, Powai, Mumbai-400 076, \\ Maharashtra, India \\ 4 Department of Chemistry, GIT, Gandhi Institute of Technology \& Management, Rushikonda, Visakhapatnam-530045, Andhra Pradesh, \\ India \\ E-mail: rammohanrao.k@gmail.com
}

Keywords: EIS, low alloy steel, plasma nitriding, potentiodynamic polarization

\begin{abstract}
This study presents the effect of plasma nitriding on corrosion resistance of low alloy $90 \mathrm{CrMoV} 8$ steel. At a selected temperature of $500{ }^{\circ} \mathrm{C}$, nitriding was performed by varying the exposure time. X-ray diffraction of nitrided steel revealed the presence of $\mathrm{Fe}, \gamma^{\prime}(\mathrm{Fe}, \mathrm{Cr})_{4} \mathrm{~N}$ and $\left.\varepsilon-(\mathrm{Fe}, \mathrm{Cr})_{2-3} \mathrm{~N}\right)$ phases. The cross section of the nitrided steel was analyzed by scanning electron microscope. To understand the effect on corrosion resistance, potentiodynamic polarization along with the electrochemical impedance spectroscopy (EIS) was performed in 3.5\% NaCl. The corrosion resistance of the nitrided steel was found to be much higher than the as-received steel. It was also found that the steel nitrided for shorter duration of $6 \mathrm{~h}$ has better corrosion resistance than that for $8 \mathrm{~h}$. This enhancement of corrosion resistance may be attributed to the presence of nitrogen in solid solution, $\gamma^{\prime}-(\mathrm{Fe}, \mathrm{Cr})_{4} \mathrm{~N}$ and $\varepsilon-(\mathrm{Fe}, \mathrm{Cr})_{2-3} \mathrm{~N}$ phases.
\end{abstract}

\section{Introduction}

Plasma nitriding has been widely accepted as an efficient and eco friendly process for the enhancement of wear, fatigue and electrochemical properties of steels and Ti alloys. Formation of nitrides and compressive stress generation in the crystal lattice may be considered for the enhancement of these properties [1-9]. Other techniques such as PVD and CVD may also improve these properties; however delamination of the coated layer limits their applications [10-13].

Plasma nitriding has been widely reported to improve the mechanical properties of various steels [3,14-21]. In this work plasma nitriding of a special steel $90 \mathrm{CrMoV} 8$ has been focused to see improvements in its mechanical properties and corrosion resistance.

During cutting or machining the tool surfaces encounter high frictional forces which cause the mechanical degradation of tool surface. At the same time, the exposure to various corrosives in the service conditions augments the degradation synergistically. It has been realized now for the widespread utilization of these steels the improvement of corrosion resistance is also necessitated.

For the best utilization of these tools, optimization of properties like hardness and resistance to wear and corrosion is warranted. In a previous study [21], the hardness of plasma nitrided $90 \mathrm{CrMoV} 8$ steel was found to be improved but there was no focus on its corrosion properties in chloride environment. It has also been shown that the nitriding at $500{ }^{\circ} \mathrm{C}$ improved the hardness significantly. At $520^{\circ} \mathrm{C}$ the core hardness was very much reduced.

Hence, in this study, nitriding was performed at $500^{\circ} \mathrm{C}$. After nitriding the corrosion in salt solution such as $\mathrm{NaCl}$ has been focused. 
Table 1. Composition of the steel.

\begin{tabular}{lccccccc}
\hline Elements & $\mathrm{C}$ & $\mathrm{Si}$ & $\mathrm{Mn}$ & $\mathrm{Cr}$ & $\mathrm{Mo}$ & $\mathrm{V}$ & $\mathrm{Fe}$ \\
\hline $\mathrm{Wt}(\%)$ & 0.5 & 1.0 & 0.5 & 8.0 & 1.5 & 0.5 & balance
\end{tabular}

\section{Materials and experimental methods}

\subsection{Materials}

The steel sheet was first heat treated to austenite temperature then oil quenched and then tempered at $530{ }^{\circ} \mathrm{C}$. The quenched and tempered martensitic steel achieved the hardness approximately $650 \mathrm{H}_{v-} \pm 30$. Then the samples were cut from the hardened sheet to a dimension of $10 \times 10 \times 3 \mathrm{~mm}^{3}$. The composition of the steel is given in table 1 .

\subsection{Methods}

Steel samples after metallographic polishing were cleaned with acetone in ultrasonic bath and then placed in the vacuum chamber of the nitriding reactor. The nitriding chamber was evacuated to $0.5 \mathrm{~Pa}$ then nitriding cycle was started with the $\mathrm{Ar}^{+}$sputtering until the desired temperature attained. Once the temperature was attained, nitriding was carried out at $500 \mathrm{~Pa}$ in glow discharge plasma of $\mathrm{N}_{2}$ and $\mathrm{H}_{2}$ gas mixture at a ratio of 80:20. Samples were negatively biased at $250 \mathrm{~V}$ and nitrided at a temperature of $500^{\circ} \mathrm{C}$ by varying the exposure time $(3,6$, and $8 \mathrm{~h})$.

Nitrided steel samples along with the as-received steel sample were subjected to the $\mathrm{x}$-ray diffraction (XRDINEL CPS 120 diffractometer- $\theta / 2 \theta$ configuration) studies using Co- $\mathrm{k}_{\alpha}(0.17932 \mathrm{~nm})$ radiation. Cross sections of the nitrided steel samples after metallographic polishing and etching with Villela's reagent were exposed to scanning electron microscope (SEM- model SEM-Jeol JSM-5900). EDS microanalysis was also followed to know the presence of $\mathrm{N}$ along with the other elements on the surface layer.

For the assessment of corrosion resistance, nitrided samples along with as-received sample were exposed to potentiodynamic polarization and electrochemical impedance spectroscopic (EIS) analysis in 3.5\% NaCl $(\mathrm{pH}=5)$ at room temperature. These tests were performed by using Biologic SP300 potentiostat with EC Lab software. For these tests, a cell consisting of nitrided sample as the working electrode with $0.636 \mathrm{~cm}^{2}$ exposed to the electrolyte, a platinum counter electrode and a saturated calomel electrode (SCE) as reference electrode was constituted. All the tests were repeated thrice for the confirmation of reproducibility of results. When the open circuit potential was stabilized after $1000 \mathrm{~s}$. the potentiodynamic polarization was carried out at $\pm 250 \mathrm{mV}$ and with a scan rate of $1.66 \mathrm{mV}$ per sec. From Tafel extrapolation on polarization transients corrosion current density $\left(\mathrm{i}_{\text {corr }}\right)$ and hence the corrosion rate was obtained.

Electrochemical Impedance spectroscopic (EIS) analyses was performed at OCP by using A.C. signals with voltage amplitude $10 \mathrm{mV}$ at the corrosion potential $\left(\mathrm{E}_{\mathrm{corr}}\right)$ and responses were measured over frequencies $10 \mathrm{MHz}$ and $100 \mathrm{KHz}$. In order to obtain the individual parameters like pore resistance $\left(\mathrm{R}_{\mathrm{p}}\right)$, film capacitance $\left(\mathrm{C}_{\mathrm{f}}\right)$, charge transfer resistance $\left(\mathrm{R}_{\mathrm{ct}}\right)$ and double layer capacitance $\left(\mathrm{C}_{\mathrm{dl}}\right)$ the data obtained was fit into equivalent electrical circuit.

\section{Results and discussion}

\subsection{Microstructural characterization}

\subsubsection{X-ray diffraction studies $(X R D)$}

The XRD patterns (figure 1) of as-received and nitrided steels revealed mainly the peaks of Fe and its nitrides $\left(\gamma^{\prime}-\right.$ $(\mathrm{Fe}, \mathrm{Cr})_{4} \mathrm{~N}$ and $\left.\varepsilon-(\mathrm{Fe}, \mathrm{Cr})_{2-3} \mathrm{~N}\right)$ are appeared. With the increase in nitriding time the volume fraction of nitrides also increased which has also been shown by other workers also [22]. $\gamma^{\prime}-(\mathrm{Fe}, \mathrm{Cr})_{4} \mathrm{~N}$ phase is more pronounced in case of longer nitriding condition i.e. for $8 \mathrm{~h}$, than $6 \mathrm{~h}$ nitriding. The Fe peak widths of nitrided steels are broadened indicating the incorporation of nitrogen in the solid solution and hence generating stresses.

The shift in the $\mathrm{Fe}(110)$ peak to the left is due to the generation of $\varepsilon-(\mathrm{Fe}, \mathrm{Cr})_{2-3} \mathrm{~N}$ phase. The reduced intensity of $\mathrm{Fe}(110)$ peak indicates the consumption of iron in forming the $\varepsilon$-nitride. It can also be seen that there is no $\mathrm{CrN}$ phase in any of the nitriding conditions which is a good indication of protectiveness from corrosion. Formation of the $\varepsilon$ - and $\gamma^{\prime}$-nitrides and also the nitrogen solid solution are responsible for the enhancement of hardness. Presence of $\varepsilon$-nitrides is already known to be beneficial from the corrosion resistance point of view. 


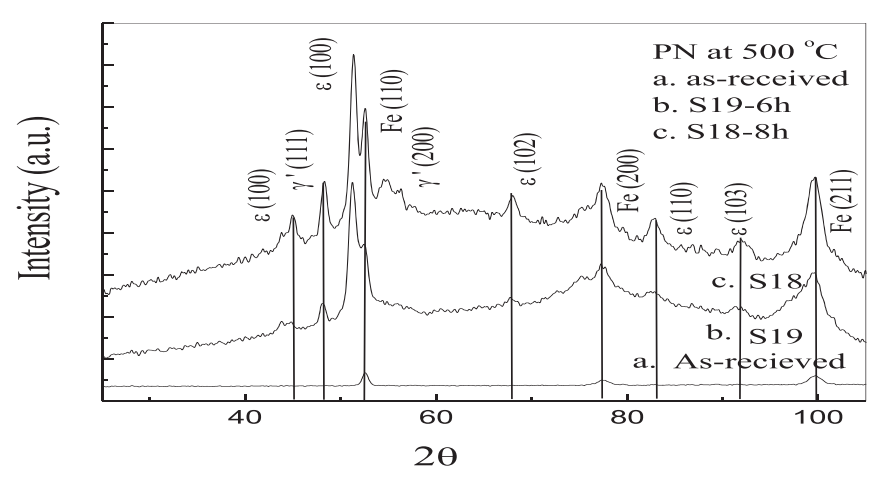

Figure 1. $\mathrm{X}$ ray diffraction patterns of the $90 \mathrm{CrMoV} 8$ steel (a) in as-received condition; and after plasma nitriding at $500{ }^{\circ} \mathrm{C}$ for (b) $6 \mathrm{~h}$; (c) $8 \mathrm{~h}$.
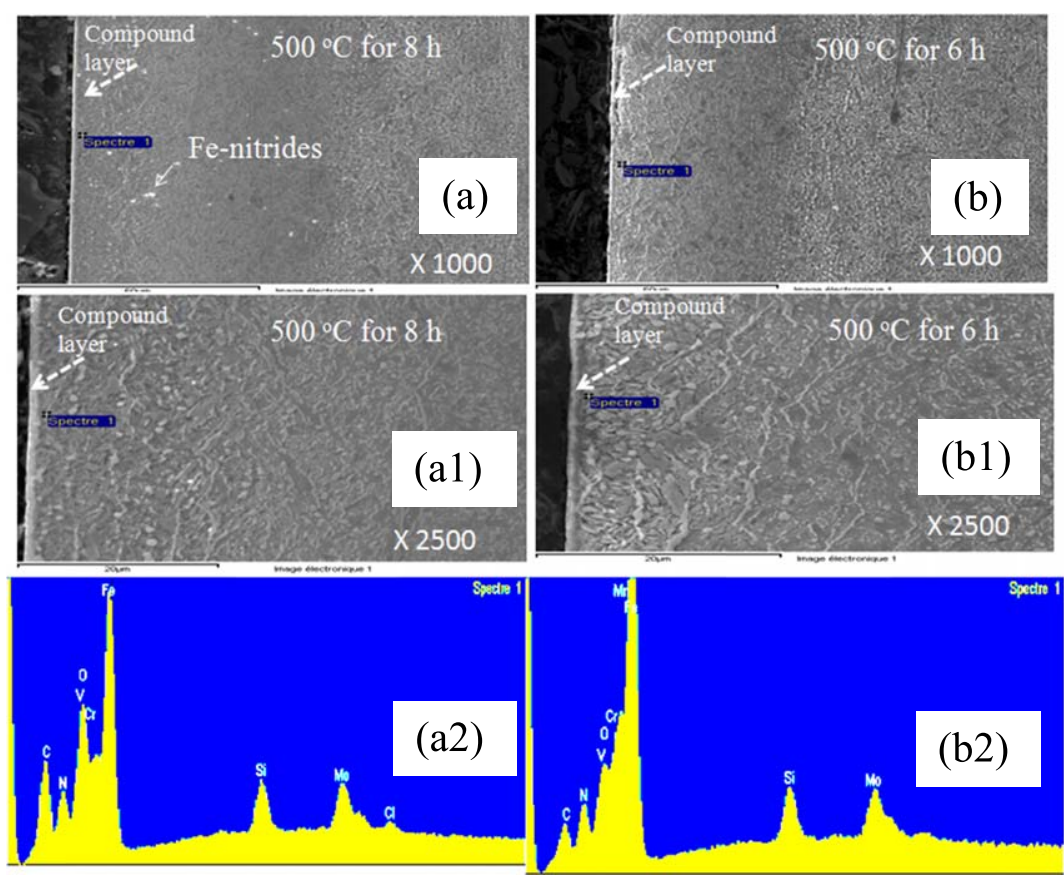

Figure 2. SEM micrographs and EDS of $90 \mathrm{CrMoV} 8$ steel after plasma nitriding at $500{ }^{\circ} \mathrm{C}$ for the duration of (a) $6 \mathrm{~h}$ (S19) and (b) $8 \mathrm{~h}$ (S18).

\subsubsection{Scanning electron microscopic analyses (SEM)}

In the figure 2, the cross sections of nitrided steel at $500^{\circ} \mathrm{C}$ for 6 and $8 \mathrm{~h}$ are shown. It is evident that a very thin and uniform compound layer formed on top of the surface. This thin compound layer is known to be beneficial from the corrosion resistance point of view. As the compound layers are brittle, its presence may degrade the wear resistance of steel. The presence of a very thin layer on the surface is the indication of the mechanical integrity.

Small bright particles in the microstructure are shown to be sporadically distributed on the diffusion layer. Forati Rad et al [20] already explained that these bright particles are formed by the agglomeration of iron nitride particles which depend on the $\mathrm{N}$ concentration. Nitriding for the shorter duration of $6 \mathrm{~h}$ may cause the nitrogen diffusion to a lesser extent than in the case of nitriding for a longer duration of $8 \mathrm{~h}$. Thus, the retention of nitrogen in the near surface region may be expected to be more in the former case which may incorporate higher concentration of nitrogen in the solid solution and also increase the concentration of nitrides.

\subsection{Electrochemical characterization}

\subsubsection{Potentiodynamic polarization tests}

Figure 3 shows potentiodynamic polarization plots of untreated (Bare) steel and the steel nitrided steel for $6 \mathrm{~h}$ (S19) and $8 \mathrm{~h}$ (S18). From the Tafel plots corrosion parameters $\mathrm{E}_{\mathrm{corr}}, \mathrm{I}_{\mathrm{corr}}$ and corrosion rate was calculated 


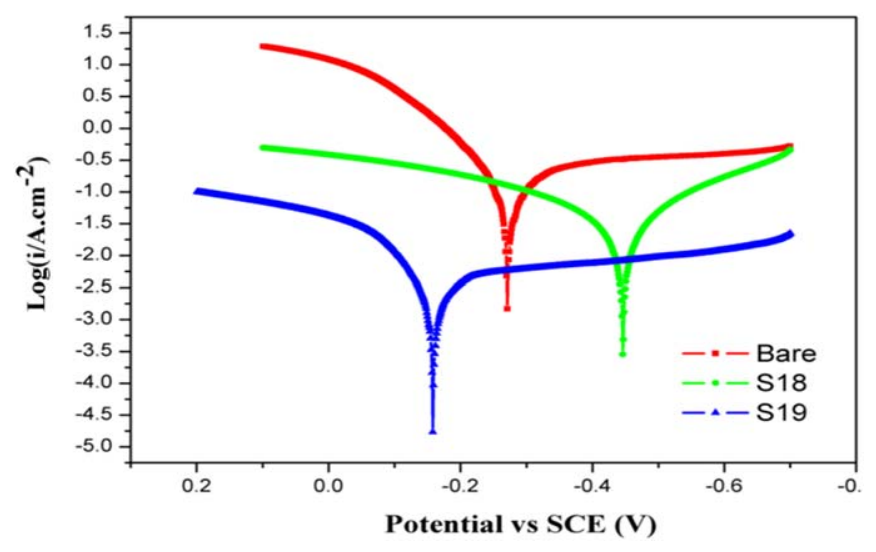

Figure 3. Potentiodynamic polarizations curves of Bare, S18 (8 h) and S19 (6 h) steels.

Table 2. Tafel extrapolation parameters.

\begin{tabular}{lccc}
\hline Steel samples & $\begin{array}{c}E_{\text {corr }}(\mathrm{V}) \\
\text { versus SCE }\end{array}$ & $I_{\text {corr }}(\mu \mathrm{A})$ & $\begin{array}{c}\text { Corr. } \\
\text { rate }(\mathrm{mpy})\end{array}$ \\
\hline $\begin{array}{l}\text { Untreated } \\
(\text { Bare })\end{array}$ & -0.271 & 193.98 & 86.48 \\
S18 $(8 \mathrm{~h})$ & & & \\
S19 $(6 \mathrm{~h})$ & -0.442 & 35.22 & 15.70 \\
\hline
\end{tabular}

which is given in table 2. When compared with the untreated steel, $\mathrm{I}_{\text {corr }}$ and hence the corrosion rate for the nitrided steels (S18 and S19) were found to be significantly lower than the barrier steel. In the figure 3 the anodic polarization curves show the trend of anodic dissolution before and after nitriding. The $\mathrm{E}_{\mathrm{corr}} /$ corrosion potential $-0.162 \mathrm{~V}$ of the $\mathrm{S} 19$ steel is more positive than the other two steel samples.

The corrosion improvement can be attributed to the presence of noble nitrides covering the underlying layer. More is the amount of nitrides the corrosion resistance is expected to be more [18]. From XRD (figure 1) though the volume fraction of nitrides for $S 18$ treated for longer time $8 \mathrm{~h}$ is more than the $S 19$ treated for $6 \mathrm{~h}$, its corrosion resistance is lesser than the latter one. This anomalous behaviour could be due to the presence of $\gamma^{\prime}-(\mathrm{Fe}, \mathrm{Cr})_{4} \mathrm{~N}$ along with the $(\mathrm{Fe}, \mathrm{Cr})_{2-3} \mathrm{~N}$, whereas in the case of $\mathrm{S} 19$ steel the latter phase was found be more which has better corrosion resistance property.

The as-received as well as steel nitrided for $6 \mathrm{~h}$ (S19) show a good passive region suggesting the retention of higher $\mathrm{Cr}$ or $(\mathrm{Fe}, \mathrm{Cr})_{2-3} \mathrm{~N}$. Steel nitrided for a longer duration of $8 \mathrm{~h}$ (S18) shows faster dissolution and keeps lower passive region. Longer duration nitriding might have caused the depletion of Cr or possibly the formation of fine precipitates of $\mathrm{CrN}$. However, further analyses are required to support this mechanism, which may be undertaken in the further studies. On the other hand, it may be expected that the longer duration nitriding would have lowered the nitrogen concentration at the surface region leading to lower concentration of $\mathrm{Fe}-$ nitrides covering the underlying surface. It can also be seen from XRD results that the $\varepsilon$ - and $\gamma^{\prime}$-nitrides are formed after $8 \mathrm{~h}$ treatment (S18) but in case of $6 \mathrm{~h}$ treatment (S16) mostly the $\varepsilon$-nitrides are formed. $\varepsilon$-nitrides as already known are beneficial from corrosion resistance point of view. Hence lower duration treatment enables the steel more protective. Various corrosion parameters are summarized in table 2.

On comparing the $\mathrm{I}_{\text {corr }}$ and hence corrosion rate of untreated steel and the one nitrided for $6 \mathrm{~h}$ (S19), it can be seen from the above table that corrosion rate of S19 sample lowered by about 85 times. Thus, a significant improvement in corrosion resistance was found by nitriding for $6 \mathrm{~h}$ thereby providing better protection to the underlying metal. On the other hand, on comparing the $\mathrm{I}_{\text {corr }}$ values and hence the corrosion rate of the nitrided steels, S19 (6 h) steel has shown about 15 times lower corrosion rate than S18 ( $8 \mathrm{~h})$ steel thereby providing better corrosion protection to the underlying metal. However, in any case, the nitrided steel much better corrosion resistance than as-received steel.

\subsubsection{Electrochemical impedance spectroscopic analyses}

For the further assessment of corrosion properties electrochemical impedance spectroscopic (EIS) analyses have been carried out in 3.5\% NaCl solution. Bode and Nyquist plots of the bare and the nitrided samples for $6 \mathrm{~h}$ and $8 \mathrm{~h}$ are shown in figure 4 . In impedance studies, $Z_{\text {real }}$ provides a measure of corrosion resistance. The higher the 


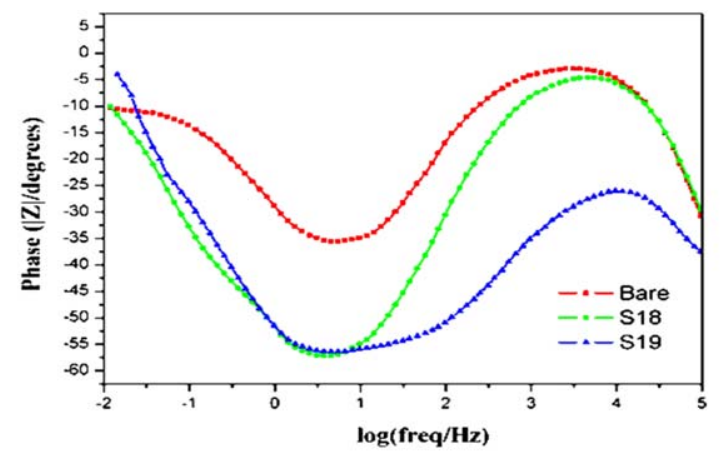

(a)

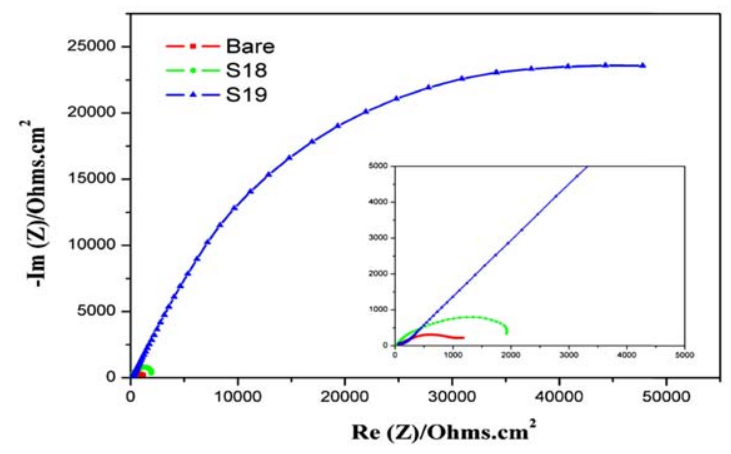

(b)

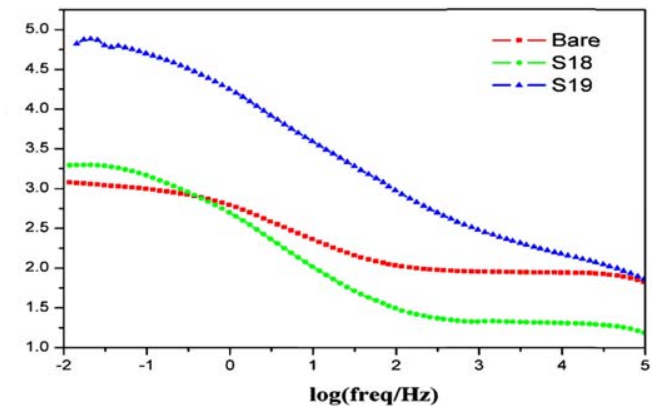

(c)

Figure 4. (a) Bode Magnitude plot (b) bode phase angle plot (c) nyquist plot.

Table 3. Calculated impedance parameters.

\begin{tabular}{|c|c|c|c|c|}
\hline & Unit & Bare & $\mathrm{S} 18\left(500{ }^{\circ} \mathrm{C} / 8 \mathrm{~h}\right)$ & $\mathrm{S} 19\left(500^{\circ} \mathrm{C} / 6 \mathrm{~h}\right)$ \\
\hline $\mathrm{R}_{\mathrm{s}}$ & Ohm.cm ${ }^{2}$ & 58.8 & 41.4 & 80.23 \\
\hline $\mathrm{Q}_{\mathrm{f}}$ & $\mathrm{F} \cdot \mathrm{s}^{(\mathrm{a}-1)}$ & & $8.68 \mathrm{E}-08$ & $1.79 \mathrm{E}-05$ \\
\hline$a_{f}$ & & & 7.97E-01 & $6.24 \mathrm{E}-01$ \\
\hline $\mathrm{R}_{\mathrm{f}}$ & Ohm.cm ${ }^{2}$ & $1.30 \mathrm{E}+03$ & $2.10 \mathrm{E}+04$ & $9.30 \mathrm{E}+04$ \\
\hline $\mathrm{Q}_{\mathrm{dl}} / \mathrm{C}_{\mathrm{dl}}$ & $\mathrm{F} \cdot \mathrm{s}^{(\mathrm{a}-1)}$ & $3.72 \mathrm{E}-04$ & $5.16 \mathrm{E}-03$ & $1.03 \mathrm{E}-02$ \\
\hline$a_{f}$ & & $6.58 \mathrm{E}-01$ & & \\
\hline $\mathrm{R}_{\mathrm{ct}}$ & Ohm.cm ${ }^{2}$ & $1.10 \mathrm{E}+03$ & $2.26 \mathrm{E}+03$ & $8.93 \mathrm{E}+03$ \\
\hline
\end{tabular}

value of $Z_{\text {real }}$, better is the corrosion resistance of the given coating. In Nyquist plots, $Z_{\text {real }}$ is measured by the total diameter of the semi circle while in Bode plots; it is the impedance value at the lowest frequency. From the plot shown, it is quite evident that the $S 19\left(500^{\circ} \mathrm{C}, 6 \mathrm{~h}\right)$ has the highest $Z_{\text {real }}$ value and hence best corrosion resistance while $\mathrm{S} 18\left(500^{\circ} \mathrm{C}, 8 \mathrm{~h}\right)$ system exhibits less corrosion resistance. Bare/as-received steel exhibits the lowest impedance values. The impedance parameters are calculated and summarized in Table 3.

The corresponding equivalent circuit, as shown in figure 5, consists of an equivalent electrical circuit (EEC) with one time constant, representing the metal/solution interface, was proposed for bare substrate. $Q_{d l}$ and $R_{c t}$, represent the electrical double layer and charge transfer resistance existing at the surface of the bare steel.

For the nitrided steels, an EEC with two time constants was proposed. Rs represents the solution resistance in all the EEC models A parallel combination of constant phase element (CPE) and pore resistance $\mathrm{R}_{\mathrm{f}}$ represent the nitride layer/solution interface while the metal/layer interface is represented by a parallel combination of capacitor $\mathrm{C}_{\mathrm{dl}}$ and charge transfer resistance $\mathrm{R}_{\mathrm{ct}}$. These two EEC models were chosen for having the lowest percentage error $(<5 \%)$ between the experimental and modelled data.

For the nitrided steels, an EEC with two time constants was proposed. Rs represents the solution resistance in all the EEC models A parallel combination of constant phase element (CPE) and pore resistance $\mathrm{R}_{\mathrm{f}}$ represent the nitride layer/solution interface while the metal/layer interface is represented by a parallel combination of capacitor $\mathrm{C}_{\mathrm{dl}}$ and charge transfer resistance $\mathrm{R}_{\mathrm{ct}}$. These two EEC models were chosen for having the lowest percentage error $(<5 \%)$ between the experimental and modelled data. 


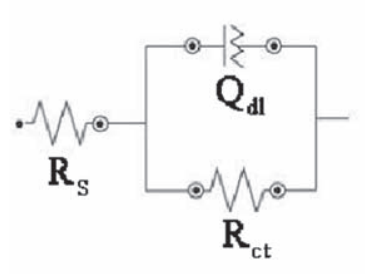

(a)

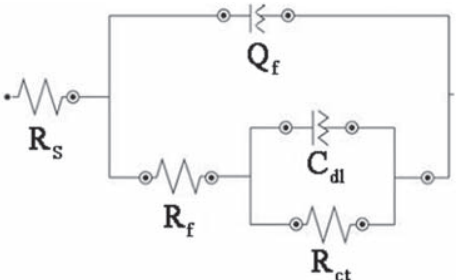

(b)

Figure 5. Equivalent electrical circuit for (a) bare; and (b) plasma nitrided steels.

Corrosion resistance of a given system is deduced from the mathematical value of $\mathrm{R}_{\mathrm{ct}}$ in the case of untreated steel and the mathematical sum of the $\mathrm{R}_{\mathrm{ct}}$ and $\mathrm{R}_{\mathrm{f}}$, also denoted as $\mathrm{R}_{\text {total }}$, in the case of nitrided steel. The corrosion resistance of nitrided steel is clearly greater than that of untreated steel. Between the two nitrided steels, $\mathrm{R}_{\text {total }}$ of $\mathrm{S} 19(6 \mathrm{~h})$ is far greater than that of $S 18(8 \mathrm{~h})$. Further, since capacitance is directly proportional to the capacitor area, low values of film capacitance $\left(Q_{f}\right)$ in the case of $S 19(6 \mathrm{~h})$ nitrided steel, compared to that of S18 (8 h) nitrided steel, is a good indication of low exposure and low electrochemical activity of the metal surface. The impedance results justify the conclusions drawn from linear polarization analyses that the S19 (6h) nitrided steel provides the best corrosion resistance among the evaluated systems.

From the potentiodynamic polarization tests it is evident that the steel nirided for $6 \mathrm{~h}$ (S19) has better corrosion resistance than nitrided for $8 \mathrm{~h}$ (S18). It has been concluded that the $\mathrm{Cr}$ retention as $(\mathrm{Fe}, \mathrm{Cr})_{2-3} \mathrm{~N}$ is more in this case which is responsible for better corrosion resistance. When the same steel treated for $6 \mathrm{~h}$ (S19) exposed to impedance analysis the corrosion resistance was again found to be better than the steel nitrided for $8 \mathrm{~h}$ (S18). This confirms that the steel nitrided for $6 \mathrm{~h}$ has better corrosion resistance than the one nitrided for $8 \mathrm{~h}$.

For the improvement of both hardness and corrosion resistance of $90 \mathrm{CMoV} 8$ steel, nitriding at temperature $500{ }^{\circ} \mathrm{C}$ for $6 \mathrm{~h}$ may be the best choice. Earlier it was shown that [21] the maximum hardness after nitriding at a lower temperature of $450^{\circ} \mathrm{C}$ was improved to $\sim 1100 \mathrm{H}_{v}$ but the case depth formed was relatively less wider than formed after nitriding at higher temperatures $\left(500^{\circ} \mathrm{C}-520^{\circ} \mathrm{C}\right)$. It has also been shown that nitriding for 6 and $8 \mathrm{~h}$ at all the temperatures $\left(450{ }^{\circ} \mathrm{C}-520^{\circ} \mathrm{C}\right.$ ) improved the hardness significantly to $\sim 1100 \mathrm{H}_{v}$ with relatively greater case depth (for $8 \mathrm{~h}$ nitriding the case depth was found to be $\sim 111 \mu \mathrm{m}$ ). A wider case depth is desirable to prolong the life of the tool in the harsh service conditions where tool surface frequently encounters frictional forces. Nitriding at the two higher temperatures 500 and $520^{\circ} \mathrm{C}$ were effective in increasing both the case depth and hardness, however at the higher temperature of $520^{\circ} \mathrm{C}$ there is the risk of loss of core hardness as shown shown earlier [21]. It was found that the core hardness was reduced to $\sim 280 \mathrm{H}_{v}$. At $500{ }^{\circ} \mathrm{C}$ there was no loss of core hardness.

In another study, plasma nitriding of AISI 52100 steel was performed in the annealed condition. The same steel was exposed to the heat treatment followed by quenching and tempering resulted in the martensitic structure of the steel and then nitrided. It was observed that the hardness of the steel in the as-received condition was improved. But after plasma nitriding the hardness for the heat treated steel was reduced to $\sim 400-500 \mathrm{H}_{v}$ from its initial hardness $\sim 700 \mathrm{H}_{v}$ [23]. The hardness for the quenched and tempered steel was reduced to $\sim 400-500 \mathrm{H}_{v}$ from its initial hardness $\sim 700 \mathrm{H}_{v}$ [23].

The reduction in hardness may be caused by the coarsening of carbides, dislocation recovery and the grain growth of ferrite. Dislocation pinning by fine precipitates results in strengthening and improving the hardness. With the rise in nitriding temperature the fine precipitates acquires the larger size and prone to coarsening and thus lowers the hardness [24]. In the present study, XRD peaks are representative of samples after nitriding at $6 \mathrm{~h}$ and $8 \mathrm{~h}$. The lower intensity of $\mathrm{Fe}(110)$ peak and conversion to $\varepsilon$-nitride suggest the hardening of the nitrided steel. Formation of fine precipitates of iron nitride hard phases and its dispersion on the surface layer may be responsible for the hardness. Also, it may be speculated that the fine precipitates of iron nitride hard phases pin the dislocation movement leading to improvement of hardness.

Hence it can be concluded that the nitriding at $500{ }^{\circ} \mathrm{C}$ is effective in improving the case depth as compared to lower nitriding at lower temperature, hardness and the corrosion resistance.

\section{Conclusions}

Plasma nitriding of low alloy $90 \mathrm{CrMoV} 8$ tool steel at $500{ }^{\circ} \mathrm{C}$ significantly enhanced the corrosion resistance. When compared to untreated steel, the nitrided steel for $6 \mathrm{~h}$ duration shows $\sim 85$ times more corrosion resistance. Furthermore, $6 \mathrm{~h}$ has nitriding has shown $\sim 14$ times higher corrosion resistance than the one nitrided 
for $8 \mathrm{~h}$. Presence of $\gamma^{\prime}$-(Fe, $\left.\mathrm{Cr}\right)_{4} \mathrm{~N}$ and $\varepsilon-(\mathrm{Fe}, \mathrm{Cr})_{2-3} \mathrm{~N}$ phases are responsible for the enhancement of corrosion resistance. To meet the requirements of wear and corrosion resistance properties, $6 \mathrm{~h}$ treatment at $500{ }^{\circ} \mathrm{C}$ would be the more desirable condition of nitriding.

\section{Acknowledgments}

The authors thankfully acknowledge GITAM (Deemed to be University) for kindly giving us the opportunity to carry out this research and granting the permission for the publication of the work.

One of the authors gratefully acknowledges the technical support extended by the team members of corrosion centre of the Department of Metallurgical and Materials Engineering, IIT Bombay, Powai, India and Ecole Nationale Superier of Art et Metiers, France.

\section{ORCID iDs}

K Ram Mohan Rao (iD https://orcid.org/0000-0001-9483-0424

\section{References}

[1] de la Cruz P, Odén M and Ericsson T 1998 Influence of plasma nitriding on fatigue strength and fracture of a B-Mn steel Mat. Sci. and Eng. A 242 181-94

[2] Oliveira Skonieski A F, Rocha dos Santos G, Karl Hirschb T, da Silva and Rocha A 2013 Metallurgical response of an AISI 4140 steel to different plasma nitriding gas mixtures Materials Research $16884-90$

[3] Maniee A, Mahboubi F and Soleimani R 2014 The study of tribological and corrosion behavior of plasma nitrided $34 \mathrm{CrNiMo}_{6}$ steel under hot and cold wall conditions Mater. Des. 60 599-604

[4] O’Brien J M and Goodman D 1991 Plasma (Ion) Nitriding, Metals Handbook (OH: American Society for Metals, Metals Park) vol 4, $420-4$

[5] Muñoz Riofano R M, Castteleti L C, Canale L C F and Totten G E 2008 Improved wear resistance of P/M tool steel alloy with different vanadium contents after ion nitriding Wear $26557-64$

[6] Cherng Wen D 2009 Microstructure and corrosion resistance of the layers formed on the surface of precipitation hardenable plastic mold steel by plasma nitriding App. Surf. Sci. 256 797-804

[7] Terres M A, Ben Mohamed S and Sidhom H 2010 Influence of ion nitriding on fatigue strength of low-alloy $\left(42 \mathrm{CrMo}_{4}\right)$ steel: experimental characterization and predictive approach Int. J. Fatigue 32 1795-804

[8] Triawani F, Nandiyanto A B D, Abdullah A G and Aziz M 2018 Plasma nitriding time on the hardness and crystal structure/phase of SUS403 and SCS6 martensitic stainless steels: an analytical study Journal of Engineering Science and Technology 13 2369-78

[9] Fernandes F A P, Carlos Picone A, Totten G E and Casteletti L C 2018 Corrosion behavior of plasma nitrided and nitrocarburised supermartensitic stainless steel Materials Research 21 1-9

[10] Roth J R 1995 Industrial Plasma Engineering, Volume 1: Principles (Bristol: IOP Publishing Ltd)

[11] Ohring M 1992 The Material Science of Thin Films (San Diego: Academic)

[12] Michler T 2008 Influence of plasma nitriding on hydrogen environment embrittlement of 1.4301 austenitic stainless steel Surf. Coat. Technol. 202 1688-95

[13] Wang L, Li Y and Wu X 2008 Plasma nitriding of low alloy steels at floating and cathodic potentials Appl. Surf. Sci. 254 6595-600

[14] Turk A and Bindal C 2009 Characterization of plasma nitrided X32CrMoV33 die steel Mater. Manuf. Process. 24 898-902

[15] Pokorny Z, Hruby V and Studeny Z 2016 Effect of nitrogen on surface morphology of layers Metall. Mater. 54 119-24

[16] Yasuhiro M, Akio N and Takajumi T $2018 \mathrm{X}$-ray residual stress in the S-phase of stainless steel nitrided by a plasma nitriding method and residual stress measurement of a dlc film deposited on the S-phase Journal of the Society of Material Science, Japan 67 715-21

[17] Li CX and Bell T 2006 Corrosion properties of plasma nitrided AISI 410 martensitic stainless steel in $3.5 \% \mathrm{NaCl}$ and $1 \% \mathrm{HCl}$ aqueous solutions Corr. Sc. 48 2036-49

[18] Mashreghi A, Soleimani S and Saberifar S 2013 The investigation of wear and corrosion behavior of plasma nitrided DIN 1.2210 cold work tool steel Mater. Des. $46532-8$

[19] Allenstein A, Lepienski C, Buschinelli A and Brunatto S F 2013 Plasma nitriding using high $\mathrm{H}_{2}$ content gas mixtures for a cavitation erosion resistant steel Appl. Surf. Sci. 277 15-24

[20] Forati Rad H, Amadeh A and Moradi H 2011 Wear assessment of plasma nitrided AISI H11 steel Mater. Des. 32 2635-43

[21] Nouveau C, Steyer P, Ram Mohan Rao K and Lagadrillere D 2011 Plasma nitriding of 90CrMoV8 tool steel for the enhancement of hardness and corrosion resistance Surf. Coat. Technol. 205 4514-20

[22] Basu A, Dutta Majumdar J, Alphonsa J, Mukherjee S and Manna I 2008 Corrosion resistance improvement of high carbon low alloy steel by plasma nitriding Mater. Lett. 62 3117-20

[23] Kumar R, Alphonsa J, Prakash R, Boob K S, Ghanshyam J, Rayjada P, Raole P M P M and Mukherjee S 2011 Plasma nitriding of AISI 52100 ball bearing steel and effect of heat treatment on nitrided layer Bull. Mater. Sci. @ Indian Academy of Sciences 34 153-9

[24] Mahboubi F, Samandi M, Dunne D, Bloyce A and Bell T 1995 Plasma nitriding of microalloyed steel Surf. Coat. Technol. 71 135-41 